\title{
AZ IDŐ ÉS A TÁVOLSÁG SZUBJEKTÍV MEGÍTÉLÉSÉNEK VIZSGÁLATA A HÓDMEZŐVÁSÁRHELY KÖRNYÉKI TANYAVILÁGBAN ÉS TANYAKÖZPONTOKBAN
}

\author{
Gálné Horváth Ildikó
}

\begin{abstract}
SUMMARY
The homesteads and farm centers peculiarly adapted to the socio-economic and geographical space, as well as accordingly residents participate in daily life. Spatial and temporal distance from the town and the socio-economic aspects are of the different farm people. The distance to the town's social impact on the lives, livelihoods of the farm population, this is subjective according to people's point of view. The study assessed many components, of which two daily routine, mail receiving and shipping, and the purchase will be presented.
\end{abstract}

\section{BEVEZETÉS}

A külterületen élö lakosok részéröl feltételezhetö, hogy a lakóhelyükből - amely gyakran munkahelyük is egyben - adódóan a távolság, illetve az anyatelepülésre történő eljutási idő megítélése eltérhet az objektív távolságról alkotott véleménytől. Ebben szerepet játszik a lakos életkora, életstílusa, melyet befolyásol anyagi helyzete, közlekedési lehetőségei, szokásai, a helyben rendelkezésére álló szolgáltatások összessége, de további paraméterek is. Életüket azonban jelentősen befolyásolja az anyatelepüléshez kötődés, amely - jelen esetben jellemzően Hódmezővásárhely. A vizsgálat jelentőségét alátámasztja, hogy Hódmezővásárhely külterületén a szórványtanyákban és a tanyaközpontokban jelentős számú, közel háromezer fös tanyai lakosság él, ami a település össznépességének mintegy 6 százaléka (Kis 2008, 2012).

\section{ANYAG ÉS MÓDSZER}

Érdekes feladat vizsgálni, milyen formában és tartalommal mérhető és értelmezhető a térben az efféle távolság és idő a tanyák és tanyaközpontok lakói körében (Lettrich 1968). Nehezen cáfolható, hogy e két dimenzió mérhetö, objektív, ennek ellenére az ember számára - különböző helyzetekben, életkörülmények között - megjelenik a szubjektív tér- és időérzet, amely különböző mértékben és intenzitással eltér az objektív értéktől. Jelen munkában multidiszciplináris megközelítésben történik a vizsgálat, mivel magát a településformát, szerkezetet, természeti környezetét és a benne élő embert, múltját, jelenét és jövőjét, azaz társadalmi környezetét tekinti tárgyának (Tóth 2010). Noha az életminőség javítása minden tanyán élőnek igénye (Mateoc-Sîrb et al. 2011), ennek ellenére vannak előnyös és hátrányos helyzetü tanyák még Hódmezővásárhely megyei jogú város külterületén belül is. A vizsgálat során többféle tanyán történt kérdöíves felmérés, az eredmények bemutatása ennek tükrében történik. 


\section{A VIZSGÁLAT ALAPJA, KONCEPCIÓJA ÉS EREDMÉNYEI}

A tanyavilág esetében 156 feldolgozható kérdőív (tanyánként 1-1 került kitöltésre), továbbá a tanyaközpontokban lakóingatlan arányosan; Batidán $18 \mathrm{db}$ (ahol 238 fö lakik 89 lakóingatlanban), Erzsébeten $11 \mathrm{db}$ (ahol 178 fö lakik 57 lakóingatlanban), Kútvölgyön $14 \mathrm{db}$ (ahol 170 fő lakik 71 lakóingatlanban) és Szikáncson $44 \mathrm{db}$ (ahol 595 fö lakik 215 lakóingatlanban), így összesen 87 db kérdöív került kitöltésre értékelhető módon. A kérdőívek kitöltése, kitöltetése addig folytatódott, amíg a kívánt számot az adott kistelepülésen (azaz tanyaközpontban), illetve tanyán sikerült elérni; a tanyák esetében a területi elhelyezkedést is figyelembe véve.

A felmérés során, a kérdöívben a tanya, illetve a tanyaközpontok környezetének felmérése is megtörtént. Itt is fontos annak vizsgálata, hogy a tanyán vagy tanyaközpontokban élő emberek mennyire elszigeteltek, mennyire érzik helyzetüket hátrányosnak a városlakókkal szemben (1. táblázat). Megjegyzendő, hogy már egy közepes nagyságú városban - például az anyatelepülésnek tekinthetö Hódmezővásárhelyen - a település speciálisan nagy kiterjedése miatt, nem ritkaság a közigazgatási határon belüli ekkora távolság és eljutási idő.

\section{1. táblázat: Elérési távolság és eljutási idő a központi belterület és a tanyaközpontok viszonylatában}

\begin{tabular}{|l|r|r|r|r|r|r|}
\hline \multicolumn{1}{|c|}{ Tanyaközpontok } & $\begin{array}{c}\text { térkép } \\
(\mathrm{km})\end{array}$ & $\begin{array}{c}\text { válasz } \\
(\mathrm{km})\end{array}$ & $\begin{array}{c}\text { eltérés } \\
(\mathrm{km})\end{array}$ & $\begin{array}{c}\text { útvonaltervező } \\
(\text { perc })\end{array}$ & $\begin{array}{c}\text { válasz } \\
(\text { perc) }\end{array}$ & $\begin{array}{c}\text { eltérés } \\
(\text { perc })\end{array}$ \\
\hline Batida & 11 & 8,8 & 2,2 & 17 & 15 & 2 \\
\hline Erzsébet & 16 & 14,7 & 1,3 & 21 & 16 & 5 \\
\hline Kútvölgy & 13 & 11,9 & 1,1 & 17 & 18 & -1 \\
\hline Szikáncs & 13 & 11,6 & 1,4 & 17 & 19 & -2 \\
\hline
\end{tabular}

A lakosság részéről tapasztalható valamiféle lokálpatriotizmus, az emberek szeretnek a külterületen - adott esetben az ősi tanyán - lakni. A városlakó számára nehezen érthető az efféle vélemény. Ebböl arra következtethetünk, hogy a szubjektív megítélés térben is időben különbözhet a bel- és külterületi lakos esetében.

Érdekes jelenség - a várakozásokkal ellentétben - hogy a tanyán lakók $(87 \%$ + 9\%) kevésbé érzik magukat elzártnak a világtól (1. ábra), mint a szorosabb közösségben élő tanyaközpontok $(52 \%+31 \%)$ lakói. Összességében világossá vált, hogy a tanyán és a tanyaközpontokban lakók nagytöbbsége szereti lakóhelyét, nem jelent számára nagy problémát a várostól többé-kevésbé távoli lét (Erdei 1942). 


\section{1. ábra: Az elszigeteltség érzésének megítélése}

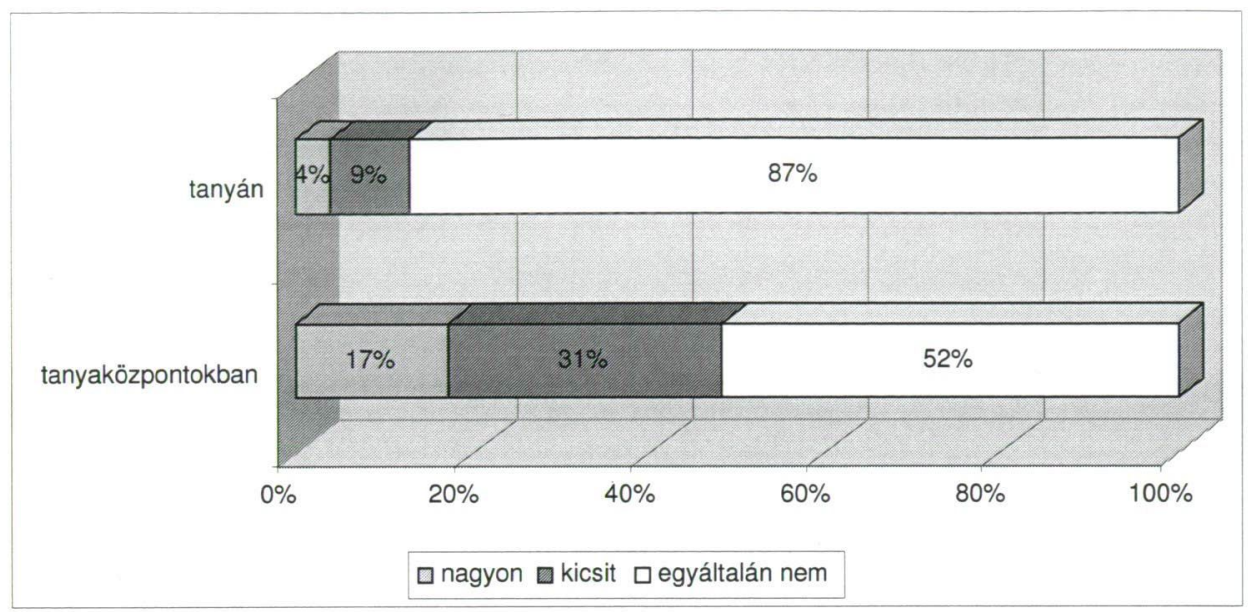

Forrás: a szerző felmérése alapján

A cél annak megismerése volt, hogy a tanyák és tanyaközpontok jövője, az életminőség javítása érdekében a lakosok mennyire nyitottak az új dolgok, szolgáltatások iránt? Ebben a tanulmányban csak a postai küldemények és a vásárlások, mint a napi rutin részét képező feladatok vizsgálata történik meg.

A tanyai lakosok levélpostai küldeményeit (2. ábra) a forgalmasabb utak mellett, az ingatlanhoz lehetöleg közel elhelyezett támponti kézbesítési helyeken kézbesítik (83\%). Ezek a szabványos ládák méretükben korlátozottak, így több küldeményfajta, továbbá a készpénz elhelyezésére nem alkalmas.

\section{2. ábra: Postai küldemények kézbesítési helye (tanyák)}

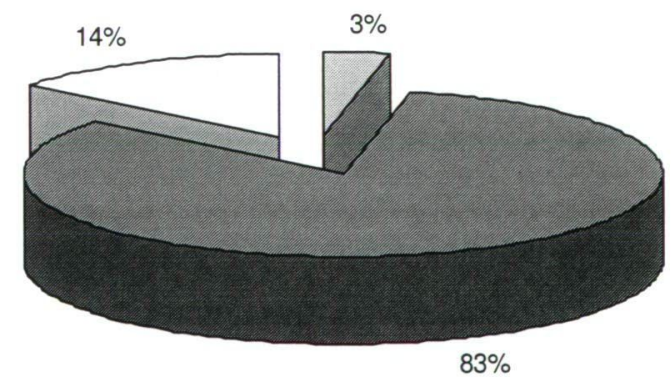

$\square$ helybe hozzák $\square$ támponti kézbesítés $\square$ városi posta

Forrás: a szerző felmérése alapján 
Távolságuk a tanyáktól - jellemzöen - 1500-2 000 m közé esnek. A támponti kézbesítőhelyek sürüségét befolyásolja a terület tanyasürüsége is, ennek megfelelöen a ritkább térségek esetében ezek a helyek 4000 méterre is lehetnek egymástól. A küldemények feladása a járatjelző alapján gépjármủvel közlekedő külterületi kezelőnél lehetséges. A jármü adott ponton áll elöre meghatározott időben és időintervallumban, ahová elmennek a lakosok küldeményeiket feladni, vagy postai értékcikket vásárolni. A postai szolgáltatások tárháza csaknem teljes, a legtöbb szolgáltatás elérhető, amely a postán rendelkezésre áll az ügyfelek számára. Azok a lakosok (melyek aránya 3\%) akiknek címre kézbesíti a posta a leveleket, még belterületinek számító lakóházban (tanyában) laknak. 14\% a városi postán oldja meg küldeményforgalmát.

A tanyaközpontok esetében (3. ábra) a többség (78\%) címre kézbesítetten kapja meg küldeményeit, a nehezen megközelíthető - jellemzően földutas - címhelyekre nem tud eljutni a postai kézbesítő kocsi, az ott lakók támponti kézbesítéssel (14\%), és a városi postán veszik át $8 \%$. A feladás itt is a járatjelző szerint közlekedő külterületi kezelönél lehetséges.

A legközelebbi boltra, illetve kocsmára vonatkozó kérdés nem értékelhető, ugyanis - valószínüsíthetö - sok helyen készül házi pálinka, bor. Ezek a nem kereskedelmi vagy vendéglátóhelyek jelentős forgalmat bonyolíthatnak le, de követhetetlenek. A tanyavilágban ma már alig találhatók boltok, a mozgóbolt még nem terjedt el, egyedül egy fagyasztott árukat forgalmazó cég jármüve jelenik meg heti rendszerességgel. Erre viszont lenne igény. Az emberek helyi boltként a tanyaközpontok boltjait értik akkor is, ha tanyán laknak. Ennek távolsága viszont hasonló lehet, mint a városi bolté, ezért 7\% döntött a helyi bolt mellett, a tanyai lakosok 93\% inkább a városban vásárol. A tanyaközpontok esetében gyakorlatilag - fele-fele arány tapasztalható.

\section{3. ábra: Postai küldemények kézbesítési helye (tanyaközpontok)}

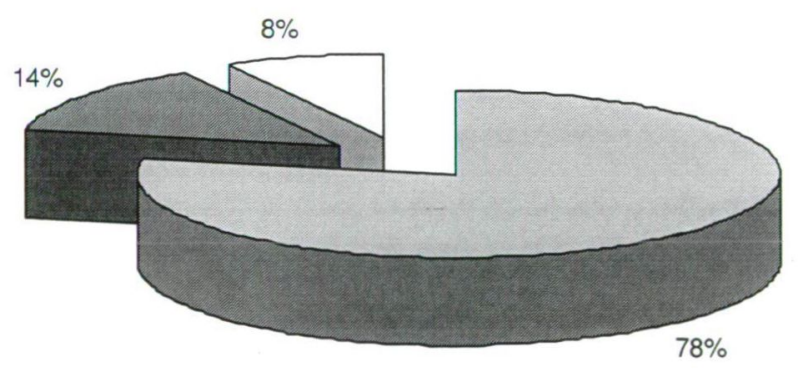

$\square$ helybe hozzák $\square$ támponti kézbesítés $\square$ városi posta

Forrás: a szerző felmérése alapján 
A bolt és a kocsma korábban fontos szocializációs hellyé vált, a találkozások, az élet nagy dolgainak megbeszélési helye, még napjainkban is. Sajnos, a tanyaközpontokban a müvelödési házak bezártak, éppúgy, mint az óvodák és az iskolák. Kivételnek tekinthető néhány külterületi, tanyai olvasókör, például Sóshalmon.

A felmérés alapján megállapítható, hogy a lakosság szinte teljes egésze rendelkezik telefonnal (elsősorban mobiltelefonnal) és egyre elterjedtebb az internet is. Ezek az új technológiák egyre szélesebb körben lehetőséget biztosítanak az elektronikus vásárlásra és ügyintézésre. A 4. ábra a következő kérdésre adott válaszokat mutatja be: „Ha lenne lehetősége interneten, telefonon keresztül megrendelni a háztartásában használt cikkeket, élelmiszert, stb. élne-e ezzel a szolgáltatással?"

\section{4. ábra: Telefonos vagy internetes vásárlási hajlandóság}

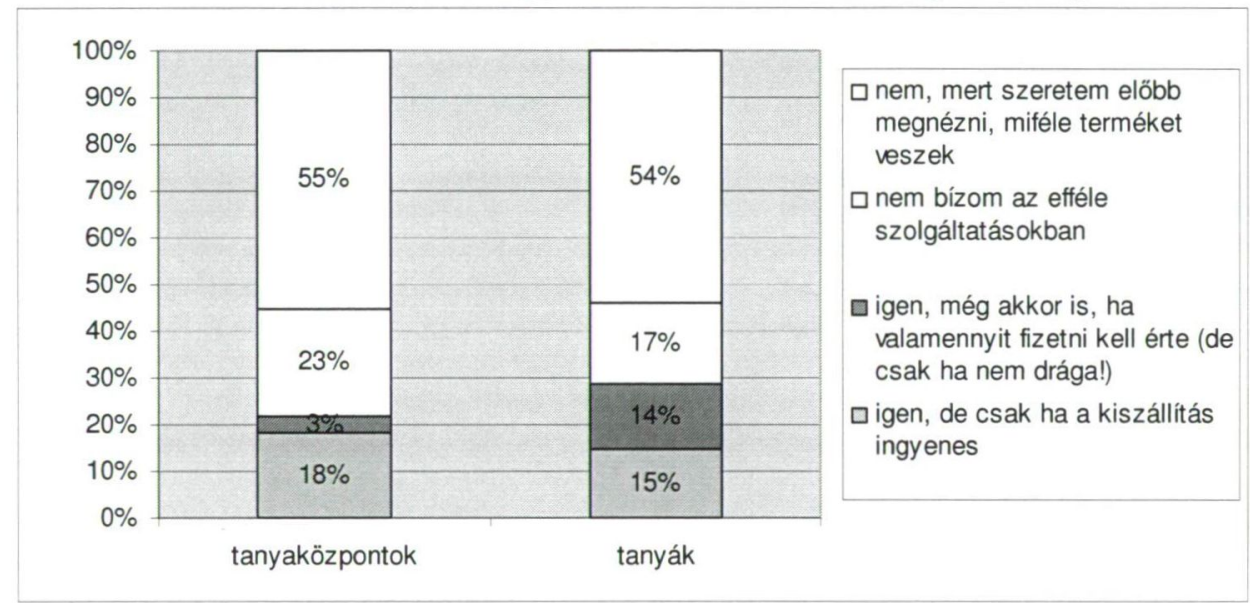

Forrás: a szerző felmérése alapján

Jelentős konzervativizmus figyelhetö meg a tanyaközpontok és a tanyák lakóiban is. Több mint felük az érzékszervi vizsgálat nélkül nem szeret vásárolni. Ehhez járul még 17-23\% abszolút elutasító, így a maradék (21\%) a tanyaközpontokban, illetve (29\%) a tanyákon elfogadó. Némiképp meglepő, hogy a tanyák lakosai nyitottabbaknak bizonyultak. Talán ennek az lehet az oka, hogy nehezebben jutnak el a boltokba, így érdekesebb lehet, ha helybe jön az áru. A szubjektív távolságérzetet csökkentenék ezek a vásárlási formák.

\section{4. ÖSSZEFOGLALÁS}

A városias elemek megjelenése a tanyákon, tanyaközpontokban, lehetővé teszik, hogy kitáruljon a világ a külterületi lakosság számára, az információk elérhetőbbé válása által a külterületi élettér és a város közti szubjektív távolságérzet csökkenthető. Az elszigeteltség érzését feltáró kérdések a várakozásokkal ellentétes arányokat adtak. Érdekes jelenség, hogy a tanyán lakók $(87 \%$ + 9\%) kevésbé érzik 
magukat elzártnak a világtól, mint a szorosabb közösségben élő tanyaközpontok $(52 \%+31 \%)$ lakói.

Összességében világossá vált, hogy a tanyán és a tanyaközpontokban lakók nagytöbbsége szereti lakóhelyét, nem jelent számára nagy problémát a várostól többé-kevésbé távoli lét. Következtetésként megállapítható, hogy a tanyavilágban és a tanyaközpontokban is szinte teljes lefedettséggel jelen van a telefonhasználat és az internet további ablakot nyit a világra. Ez azonban csupán lehetőség, nagyon nagymértékben függ attól, hogy az adott személy, család vagy más közösség mennyire nyitott a modern technika és technológia használata iránt, így a jövőkép, a közeli és távolabbi jövő megítélése is nagyon eltérő lehet.

Továbbra is érdekes, hogy egyfajta aszimmetria megmarad, másként látja a városi ember a tanyai életformát, a tanyaközpontok lakosságát, mint fordítva. Egy olyan világ kudarcra ítéltnek tủnő jövőjéről hallani, amely sok értéket, szeretetet és megélhetést hordoz. A Hódmezővásárhely környéki tanyavilágnak, Batidának, Erzsébetnek, Kútvölgynek és Szikáncsnak van jelene és lesz jövöje, melynek elöfeltétele a kor igényeihez igazodó gazdálkodási, megélhetési forma és a korszerü technika, technológia vívmányainak alkalmazása. A külterületi lakosság életét segíteni kell, azokat, akik akarják, hogy legyen vidéki jövő.

\section{IRODALOMJEGYZÉK}

Erdei F. (1942): Magyar tanyák. Athenaeum Kiadó, Budapest.

Kis K. (2008): A Hódmezővásárhelyi kistérség humán erőforrásainak hierarchia-rendszerü vizsgálata. Agrártudományi Közlemények, 2008/29. pp. 91-110.

Kis K. (2012): A vidéki eröforrások helyzete és szerepe a Hódmezővásárhelyi kistérség gazdaságában. Doktori $(\mathrm{PhD})$ értekezés. Debreceni Egyetem, Ihrig Károly GSZDI, Debrecen.

Lettrich E.(1968): Az Alföld tanyai település és gazdálkodási rendszere. Földrajzi közlemények, 1. pp. 21-39.

Mateoc-Sîrb, N. - Toth, G. C. - Mateoc, T. - Ţărău, D. - Matiaș, C. - Venig, A. - Sârb, G. S. (2011): Possibilities to Improve the Life Quality in Rural Areas and the Diversification of Rural Economy. Management Agricol, Scientific Papers - Agricultural Management. Banat's University of Agricultural Sciences and Veterinary Medicine. Timisoara, Romania. Seria I, Vol. XIII. pp. 7-14.

Tóth J. (2010): Településföldrajz. In: Tóth J.(szerk): Világföldrajz, Akadémiai kiadó, Budapest. pp. 323-358. 